\title{
The geography of logistics firm location: the role of accessibility
}

\author{
Adelheid Holl ${ }^{1 *}$, Ilaria Mariotti ${ }^{2}$ \\ ${ }^{1}$ CSIC - Institute of Public Goods and Policies \\ ${ }^{2}$ DAStU - Politecnico di Milano
}

\begin{abstract}
Sommario
The organization of modern economies is built upon an efficient transport system and an increasing role is played by the logistics sector in overcoming the constraints of time and distance in modern supply chains. While a large body of literature is dedicated to the spatial distribution of firms and firm location choice in general, surprisingly little is still known about the location patterns of logistics firms, and more specifically about the role of accessibility in their location decisions. We use geo-referenced firm level data along with detailed information on transport infrastructure in order to investigate the geography of logistics firms in Spain. We place specific attention to the relationship between logistics firm location, accessibility, and urban structure. Our results show that these firms are located closer to highways and other transport infrastructure compared to other sectors and that the logistics sector is highly urbanized. Yet, they are also locating increasingly in suburban locations and to some extent in extra-urban locations with good accessibility while central cities of urban areas have experienced a declining share of logistics firms.
\end{abstract}

Parole chiave: logistics, location, accessibility, urban structure, Spain

\section{Introduction}

With the increasing need to transport quickly and efficiently, transport and logistics play a key role in overcoming the constraints of time and distance in modern supply chains. This is even more true in a context where firms are facing competition that is ever more global. Firms are now concentrating more on specific consumers' requests, on delivering goods with greater speed, seeking ways to reduce costs, and improving quality (Bonacich and Wilson 2008). To achieve these ends, firms formulate intelligent strategies, including the use of international logistics techniques to gain competitive advantage in the management of supply chains (Wood et al. 2002). Indeed, logistics is becoming increasingly popular as a competitive device for companies to reduce delivery times, increase reliability and flexibility in deliveries, heighten customer responsiveness, and facilitate the successful implementation of Just-In-Time (JIT) manufacturing and distribution systems (Lai and Cheng 2009; Brouwer et al., 2011). Since the 1950s, indeed,

\footnotetext{
* Corresponding author: Ilaria Mariotti (ilaria.mariotti@polimi.it)
} 
the logistics industry has experience the so-called "logistics revolution" that can be explained with five interrelated phenomena: (i) the consumer-oriented economy demanding a level of service customization and delivery speed which is only possible if more frequent shipments of goods are made ; (ii) Internet-based information systems; (iii) the substantial reductions of trade barriers, tariffs and transportation costs; (iv) the European Traffic Policy; and (v) the processes of vertical disintegration and value-chain decomposition in most industries associated with the ongoing globalization of the economy that has increased the amount of goods flows to be moved around the globe (Maggi and Mariotti, 2012; Mariotti, 2015).

The consumer-oriented economy, which is geared to mass consumption, mass production, and the mass distribution of consumer goods (Strasser, 1998), has heightened the complexity of logistics processes in production and trade. The management of such complexity has been made feasible by the Internet-based information systems developed in the 1990s. These systems have made the exchange of information drastically simpler and cheaper, while Internet-based mail order businesses have boosted parcel services. Moreover, a key role has been played by various technology innovations in freight moving and handling: for instance, the rapid growth in roll-on, roll-off trucking technology, gains in containerization technology and capacity, rapid-turnaround shipping and the increased speed and efficiency of air transport technologies (McCann, 2008).

All of these technological developments have contributed to a huge reduction in transport costs (Hummels, 1999; van Veen-Groot and Nijkamp, 1999; Glaeser and Kohlhase, 2004; Levinson, 2006; Notteboom, 2007; McCann, 2008; Notteboom and Rodrigue, 2009; Coto-Millàn et al., 2015). In particular, during the twentieth century the costs of moving goods declined by over $90 \%$ in real terms, and this reduction is continuing. Indeed, the average cost of transporting a ton a mile decreased from 18.5 cents in 1890 (in 2001 dollars) to 2.3 cents in 2004 (Glaeser and Kohlhase, 2004). At the same time, the EU Traffic Policy intended to favour the liberalization of truck traffic has greatly increased the truck fleet and traffic flows in the Europe. In around only ten years, from 1990 to 1999, road traffic within European member states increased by $76 \%$ (Vahrenkamp, 2010).

Moreover, the globalization of the economy has strongly affected transport and logistics. Vertical disintegration is linked to the post-Fordist paradigm, which promoted the switch from the mass production of standardized goods to the market-oriented production favouring so-called flexible specialization. Finally, in an increasingly globalized environment, logistics has also become one of the main engines of competitiveness and economic development (see also Xiushan et al., 2015). If a country is to become competitive in the global scenario, it should improve the quality of logistics services, develop and enhance the logistics infrastructure, promote the cooperation and coordination among logistics services providers, invest into IT, reduce logistics costs, and increase training on all aspects of supply chain management. As stressed by the literature, there is a bidirectional link between economic development and logistics performance (see Arvis et al. 2007; Ferrari et al., 2011).

These trends have significantly changed the geography of freight distribution and logistics and the way goods move through the economy. Yet, although transport and logistics are factors in a country's competitiveness, and logistics activities have experienced enormous, largely unnoticed, growth in recent years (Bowen, 2008), research into this topic is generally underrepresented in regional science and economic geography (Hesse and Rodrigue, 2004). Besides, while the literature on manufacturing firm location 
is extensive, highlighting the role of accessibility as one of the key variables in firm location decisions (see, for example, Reggiani, 1998; Head and Mayer, 2004; Holl, 2004; Rietveld and Bruinsma, 2012), surprisingly little is still known about the location patterns of logistics firms and how accessibility considerations shape this pattern.

Nevertheless, it cannot be denied that understanding the location decisions of transport and logistics firms is important for the society because the demand for "logistics floor space" is expected to grow substantially in advanced economies, while the demand for "industrial floor space" is expected to decline (McKinnon, 2009). The expected growth in logistics floor space is correlated with the predicted growth of freight transport volumes, which is estimated in the EU to reach about 82\% in 2050 (European Commission, 2011). It is, therefore, crucial to investigate the location decisions of transport and logistics firms for policy makers since it has a huge impact on the demand for freight transport, and the choice of freight transport modes (Bowen, 2008). Besides, the location of logistics activities enters the policy debate since it raises land consumption and contributes to urban sprawl (Van Den Heuvel et al., 2013).

The scant literature on the location choice of transport and logistics concerns mainly logistics sprawl, with a focus on warehousing location at regional/metropolitan level, and the location choice of transport and logistics foreign direct investments (FDIs) at national level. Only the work by Bowen (2008) and Verhetsel et al. (2015) analyze explicitly the role played by accessibility measures related to several kinds of transport networks in fostering warehousing location in US in 1998-2005 and in influencing location choice of logistics companies in Flanders (Belgium) respectively.

Our paper contributes to fill the gap in the literature by investigating the geography of logistics firms in Spain in the period 2002-2007, and specifically the relationship between logistics firm location, accessibility, and urban structure at a spatially disaggregated level. To reach this goal, we use geo-coded firm level data from the SABI database (Sistema de Análisis de Balances Ibéricos), generated by INFORMA and Bureau Van Dyck, along with detailed information on transport infrastructure, accessibility measures, and municipality characteristics. By combining our geo-coded data for the whole of mainland Spain with Geographic Information System (GIS) techniques, this paper is the first to provide a comprehensive spatially detailed quantitative analysis of the geography of logistics firm.

We organize our empirical analysis in two parts. First, we carry out a spatial analysis to explore the geography of logistics firms compared to other sectors (manufacturing, business services, and transportation) regarding access to transportation infrastructure and urban structure. Second, we study the location behaviour of new logistics firms born in 2002-2007 and the role played by accessibility using an econometric analysis. Specifically, we apply a Poisson model and examine the robustness of our results to the use of a negative binomial model as well as a zero-inflated negative binomial model.

We provide evidence that logistics firms are located closer to highways and other transport infrastructure compared to other firms (manufacturing, business services, and even transport operators). Besides, they are strongly attracted to urban areas (mainly Madrid and Barcelona) for their market size and market potential, but also increasingly to suburban locations and, to some extent, extra-urban locations that have good accessibility. In contrast, central cities of urban areas have experienced a declining share of logistics firms. Recent research for the US (Bowen, 2008; Dablanc et al. 2014) has highlighted this phenomenon of sprawl in relation to warehousing. We provide empirical evidence based on the logistics sector and in a European context. The results of the 
econometric analysis confirm that logistics firms are strongly attracted by access to transportation infrastructure (especially highways) and large markets.

The paper is structured into five sections. The introduction is followed by the literature review on the location patterns of logistics firms. Section three is dedicated to data description while the empirical analysis and its results are described and discussed in section four. Section five presents conclusions and policy recommendations.

\section{Literature Review}

The location determinants of the transport and logistics industry are closely bound up with the features of the services that it furnishes. First, logistics activities are intermediate inputs, so that the demand for logistics services derives from the demand for final goods or services. Moreover, customers' preferences significantly affect the behaviour of logistics providers. Second, logistics services are business services. They are typically non-traded or furnished at much higher costs from a distance (Daniels, 1985; Markusen et al., 2005). Consequently, the use of logistics services provided from another region implies distance related coordination costs. Third, business services are normally produced with internal economies of scale (Groot, 2001) due to high set-up costs. Finally, logistics services are largely customized because customers normally have particular requirements and need differentiated logistics services.

The few studies on the location patterns of the transport and logistics industry belong mainly to two strands of literature: one referring to logistics sprawl that has largely focused on the location of warehousing activities at regional/metropolitan level; the other investigating the location determinants of transport and logistics FDIs at national level. The studies of the first group refer to the USA (Bowen, 2008; Dablanc and Ross, 2012; Dablanc et al., 2014), the Netherlands (Van Den Heuvel, 2013), Belgium (Vanhetsel et al., 2015), the UK (Allen and Browne, 2010), and Germany (Hesse, 2004). The studies of the second group refer to China (Oum and Park, 2004; Hong and Chin, 2007; Hong, 2007; 2010), and Italy (Boscacci et al., 2009; Mariotti et al., 2012; Mariotti, 2015).

The most closely related study to ours are Vanhetsel et al. (2015) and Bowen (2008). Vanhetsel et al. (2015) study the role of accessibility and land rents in the location choices of logistics firms in the Flanders region in Belgium by means of a stated preference analysis among 100 respondents. Based on data for the 200 largest logistics companies, they furthermore present information on actual location patterns in relation to access to transportation infrastructure. This shows that the logistics firms analyzed are located at very short distances of transportation infrastructure. The stated preference analysis revealed land rents as the most important location factor followed by access to sea ports and access to motorways while rail terminal access showed no significant role.

Bowen (2008) studies the relationship between the location of warehouses and accessibility measures of several kinds of transport networks in the US between 1998 and 2005 at the county level. He finds that highway accessibility matters more than rail and especially more than sea accessibility, and concludes that the significant speed advantages air and road transport have over maritime and rail transport are important. This implies that those communities with good accessibility in air and highway networks stand to benefit most from the new emphasis on supply chain management, but they will also of course bear the costs of increased inbound and outbound goods traffic.

Dablanc et al. (2014) is another study looking at warehousing sprawl. They analyze the sprawl of warehouses in 1998-2009 in Los Angeles and Seattle Metropolitan Areas. It 
results that while warehousing in Los Angeles considerably sprawled, with an average distance increase of over 6 miles, in Seattle the region remained relatively stable, showing a slight decrease in average distance from the geographic centre. These different location patterns may be related to the specificities of the two metropolitan areas: Los Angeles is a very large metropolitan area while Seattle is a smaller one, and as known, logistics sprawl is typical of large metropolitan areas that serve both as trade nodes to the entire region/country as well as enormous consumer markets. Another aspect concerns land availability, and its cost (Sivitadinou, 1996): in Seattle, at the end of the 1990s, large land parcels, close to ports, airports and freeways, were available for logistics, while in Los Angeles cheap land in suburban and extra-urban areas fostered logistics sprawl. Finally, government policies may have played a role in the accommodation of new logistics functions in the two areas. Specifically, in Los Angeles logistics sprawl has been fostered, on one side by tailored actions undertaken by suburban communities to encourage growth, and on the other side by the lack of legislature to discourage growth.

Van der Heuvel et al. (2013) investigate the role of spatial clustering in location decisions in the south Dutch province of North Brabant in 1996-2009. It results that logistics employment is spatially concentrated in the so-called Absolute and Relative Employment Concentration Areas (AREC areas). These areas are also more likely to host large logistics establishments than smaller ones because the latter may be deterred by agglomeration diseconomies (i.e. high land/lease prices). Besides, the logistics establishments that relocated within the province choose relatively often AREC areas, while transportation establishments locate relatively often in areas that became AREC areas in the future, in order to avoid possible disadvantages of logistics co-location, like congestion and higher land prices. It is shown that logistics employment grows faster in areas with at least one intermodal container terminal than in areas without one.

Allen and Browne (2010) find that warehousing tend to move away from urban areas to suburban areas in the UK and elsewhere in Europe, mainly because of land prices. Besides, the authors find that in England warehousing districts are often strategically clustered along motorways but just outside large cities. The location of warehousing is, indeed, partly due to accessibility to the road network and partly a result of planning policy.

Finally, Hesse (2004) analyses two case studies in Berlin-Brandenburg Germany - a publicly developed integrated freight centre and a dispersed logistics site - and finds that rising locational competition contributes to accelerated land consumption and further dispersal. Logistics activities tend to favour distant locations for many reasons, some of which are specific to this industry, while others apply to many economic sectors: overcoming congestion, planning requirements, or even the influence of unions.

The studies concerning the cases of China and Italy refer to the decisions by multinational enterprises (henceforth MNEs) about where to locate their affiliates (i.e. FDIs) in the transport and logistics industry. China hosts a logistics market still in its infancy, which creates increasing opportunities for investors, while Italy presents a poor supply of integrated logistics, and a related increasing demand for high value added logistics services. The analyses focusing on China can be classified into two groups: those investigating location determinants per se (Oum and Park, 2004; Hong and Chin, 2007), and those analyzing the impact of firm-specific effects (i.e. firm type - branch firm or independent firm -;country of origin; age) on location decisions (Hong, 2007; Hong, 2010). 
Transport and logistics FDIs tend to be responsive to market size and market demand; they, therefore, prefer areas with strong industrial bases and tend to locate where the customers are willing to outsource logistics services to external providers (for a review see, Mariotti, 2015). The availability of skilled labour is an important location determinant, especially when inward FDIs are in the more value added activities (multimodal transport operators and freight forwarders), as in the Italian case. Also high labour costs deter inward FDIs in China, reflecting foreign investors' efforts to reduce operational costs (Hong, 2010). The number of existing logistics service providers may influence the location choice of foreign logistics firms, thus confirming the existence of agglomeration economies in logistics. Foreign investors, indeed, suffer from adverse asymmetry in information costs compared with insiders (Radner, 1992; Casson, 1994; Mariotti and Piscitello, 1995). Therefore, the opportunity to reduce information costs as well as to share spillovers from foreign agglomeration will be greater in areas affected by FDI penetration for a longer period (Guimarães et al., 2003; Hong, 2007; Mariotti et al., 2012). Besides, even cultural and geographical proximity (Hofstede, 1980) plays a key role: MNEs from Hong Kong, Macao and Taiwan are more likely to locate in Southern China.

Transportation infrastructures are important factors since they drive the internationalization of many service companies, especially in activities that require close relationships between customers and suppliers, and/or their geographical proximity (Oum and Park, 2004; Hong and Chin, 2007; Hong, 2007, 2010; Bowen, 2008; O'Connor, 2010; Mariotti et al., 2012). Government policy can be successful in attracting FDIs (Van Den Heuvel et al., 2013) by fostering, for ex-ample, the development of Special Economic Zones and Open Costal Cities, as in the case of China (Head and Ries, 1996; Hong and Chin, 2007).

Some distinctive characteristics of the logistics industry should be noted, such as the importance of good transport networks, an efficient bureaucracy as regards administrative and customs procedures, and a high degree of government regulation. This last, in fact, in the case of China, made roadway infrastructure an unimportant consideration before the mid-1990s. However, when the Chinese government reduced the restrictions about the provision of roadway transport services by foreign firms, transport conditions became a key consideration for inward FDIs (Hong, 2010).

\section{Data}

Firm level data: Our firm level data comes from the SABI data base, which corresponds to the Iberian section of the Amadeus database. The database contains annual accounts of more than 1 million Spanish firms and includes their geographic co-ordinates, the year the firm was created and its industry among other firm-level characteristics.

To identify logistics firms we use the four-digit level of the 2009 National Classification of Economic Activities (CNAE 2009). SABI included 8,959 firms in Spain that belonged to the logistics sector (CNAE 5210-5229) in the year 2007.1 Of this, about $14 \%$ were warehousing and storage firms, $31 \%$ logistics firms providing services related to land transportation, $12 \%$ related to water transportation, $3 \%$ related to air transportation, $6 \%$ of logistics firms were engaged in cargo handling, and 34\% in other transportation support

\footnotetext{
${ }^{1}$ According to the Directorio Central de Empresas (DIRCE), there were 14,484 logistics firms in 2007.
} 
activities. Note, we focus specifically on logistics firms. This group does not include transport operators.

Using the geographic coordinates, we have geo-coded all firms in ArcGIS.2 This allows us to relate our firm level data to geo-referenced digital vector maps of the Spanish transportation networks. Specifically we relate firms to the highway network (for more detail, see, Holl, 2016), airports and seaports. Note, we do not include the rail network in our analysis because it is generally not found significant for firm location, and it is not of great relevance for freight movements in Spain. Only approximately $4 \%$ of all merchandise movements in Spain are by rail, a percentage that is considerably below the EU average.

Having geo-coded data means, the exact distance from each firm to the transportation network can be calculated and the firm-level data can be integrated with other spatial data on a fine-grained spatial scale.

Accessibility variables: Our first measure of accessibility is closely related to the concept of market potential (Harris, 1954) where accessibility is determined by the distance to and the size of markets in alternative locations. Market potential in location $\mathrm{j}$ is the sum of the market size in all other locations $\mathrm{Mk}$ (proxied here by municipality population) divided by their distance djk to $\mathrm{k}$. Distance here is measured by the travel time along the road network.

$$
M A_{j}=\sum_{k} \frac{M_{k}}{d_{j k}}
$$

The measure reflects the volume of economic activity a given location has access to after taking into account the cost of overcoming distance.

With the current changes in industrial organisation towards increasingly interconnected production, transport and communication processes, location near specific transportation infrastructure such as highways, airports or seaports can provide additional advantages in terms of access to customers, production and value chains. Using our geo-coded firm level data together with the geo-coded transportation infrastructure, we have calculated the distance from each firm to its nearest highway, its nearest airport and its nearest seaport. 3

Municipality characteristics: Spain is divided into nearly 8.000 municipalities. We add controls regarding socio-economic and physical geography characteristics of municipalities that might influence the location of logistics firms. We also include data on the urban characteristics of municipalities. Here, we use the definition of Spanish urban areas from the AUDES methodology (Ruiz, 2010), which combines land use continuity and commuting criteria at the municipal level to establish central city (CBD) municipalities plus their surrounding built-up areas (suburban areas). With this information, we create three categories of municipalities: rural areas, suburban and CBD

\footnotetext{
${ }^{2}$ Note, we have used only firms in mainland Spain.

${ }^{3}$ All airports with more than 1 million passengers in 2007 have been included. Alternatively, we have also tested for cargo airports but main results are very similar. All seaports of general interest to the state as outlined in the Ministry of Public Work's Annual Yearbooks have been included.
} 
municipalities. We furthermore calculate different distances to urban areas. Variable definitions and data sources are summarized in Appendix 1.

\section{Empirical analysis}

Our empirical analysis is organized in two parts. First, we carry out an exploratory spatial analysis where we investigate the geography of logistics firms and compare their spatial pattern to the location patterns of other firms, namely, manufacturing firms, business firms and transport operators in the year 2007. Second, we estimate count data models to investigate the location determinants of new logistics firms that have been created in 2002-2007 (both years inclusive), and focus on the specific role of accessibility.

\subsection{Exploratory analysis of the location patterns of logistics firms}

Starting with our exploratory spatial analysis, Table 1 shows the distribution of logistics firms by municipalities. Logistics firms concentrate in a fairly small number of municipalities. More than $85 \%$ of Spanish municipalities have no logistics firms at all and about $10 \%$ of municipalities have less than 5 logistics firms. The remaining $1.7 \%$ of municipalities shows more than 10 logistics firms with 11 municipalities that have over 100 logistics firms. These $1.7 \%$ of municipalities concentrate three quarters of all Spanish logistics firms. Two municipalities stand out: Madrid and Barcelona each one house about 1,000 logistics establishments. Taking into account also their suburbs, the two urban areas house about a third of all logistics establishments. This numbers confirm the strong spatial concentration of logistics firms in specific urban areas (Bowen, 2008; Jing and Cai, 2010; van den Heuvel et. al., 2013).

Table 1. Number of logistics firms by municipality: 2007

\begin{tabular}{lrr}
\hline Number of new logistics firms & \multicolumn{2}{c}{ Municipalities } \\
& No & $\%$ \\
\hline 0 & 6781 & 85.3 \\
1 to 5 & 897 & 11.3 \\
5 to 10 & 136 & 1.7 \\
10 to 20 & 67 & 0.8 \\
20 to 100 & 59 & 0.7 \\
100 and more & 11 & 0.1 \\
\hline
\end{tabular}

Next, we map our logistics firms (note, these are firms in SABI that were active in 2007) together with the 2007 road network (Figure 1 in Appendix). In addition to the concentration in the Madrid and Barcelona area, one can also observe some concentration around other major cities, but also along major transportation corridors. Figure 2 in Appendix provides a zoom-in for the Madrid and Barcelona area. Again, the relevance of the road network stands out. 
Table 2. The geography of logistics firms compared to other sectors: 2007

\begin{tabular}{|c|c|c|c|c|}
\hline & Manufacturing & Business services & Transportation sector & Logistics sector \\
\hline \multicolumn{5}{|l|}{ Mean distance to: } \\
\hline 2007 Highway network & 4.5 & 2.8 & 4.9 & 2.4 \\
\hline Main airport & 53.2 & 39.0 & 56.6 & 37.4 \\
\hline Seaport & 97.7 & 109.9 & 99.4 & 93.3 \\
\hline Province capital & 24.6 & 16.5 & 25.0 & 16.2 \\
\hline Main metropolitan CBD & 34.0 & 24.9 & 37.5 & 23.2 \\
\hline Urban areas CBD (AUDES) & 13.3 & 7.8 & 14.3 & 8.0 \\
\hline $\begin{array}{l}\text { Mean population density of the } \\
\text { municipality where the firm is } \\
\text { located }\end{array}$ & 21.9 & 39.0 & 19.5 & 41.6 \\
\hline \multicolumn{5}{|l|}{$\%$ of firms in: } \\
\hline $1 \mathrm{~km}$ from 2007 highway & 37.5 & 40.6 & 36.2 & 46.0 \\
\hline $5 \mathrm{~km}$ from 2007 highway & 79.6 & 89.6 & 78.0 & 91.7 \\
\hline $10 \mathrm{~km}$ from 2007 highway & 88.2 & 94.8 & 86.4 & 95.9 \\
\hline Urban areas (AUDES) & 73.0 & 88.0 & 70.9 & 89.1 \\
\hline CBD location & 35.9 & 64.4 & 39.2 & 62.1 \\
\hline Suburban location & 37.1 & 23.7 & 31.7 & 27.0 \\
\hline Rural location & 27.0 & 12.0 & 29.1 & 10.9 \\
\hline
\end{tabular}


Table 3. Characteristics of rural municipalities with and without new logistics firm location between 2002-2007.

\begin{tabular}{|c|c|c|c|c|}
\hline & $\begin{array}{c}\text { Rural municipalities } \\
\text { without logistics firms }\end{array}$ & $\begin{array}{c}\text { Rural municipalities with } \\
\text { logistics firms }\end{array}$ & $\begin{array}{l}\text { t-test of means } \\
\text { difference }\end{array}$ & sig. \\
\hline Market potential index & 13.8 & 14.8 & -5.28 & $* * *$ \\
\hline Highway distance & 26.7 & 15.7 & 7.81 & $* * *$ \\
\hline Airport distance & 118.4 & 83.2 & 9.87 & $* * *$ \\
\hline Seaport distance & 153.7 & 102.8 & 9.18 & $* * *$ \\
\hline Population & 1206.6 & 9057.7 & -42.15 & $* * *$ \\
\hline Population density & 28.8 & 131.3 & -14.10 & $* * *$ \\
\hline Manufacturing employment & 82.4 & 731.8 & -34.45 & $* * *$ \\
\hline Distance to urban CBD municipality & 41.1 & 34.3 & 5.41 & $* * *$ \\
\hline Distance to Madrid & 26.0 & 33.0 & -9.13 & $* * *$ \\
\hline Distance to Barcelona & 48.9 & 52.7 & -2.88 & $* * *$ \\
\hline
\end{tabular}

Note: $* * *$ significant at the $1 \%$ level; $* *$ significant at the $5 \%$ level; *significant at the $10 \%$ level. All characteristics refer to the year 2001 . 
In Table 2 we show the location pattern of the logistics sector to those of other sectors. Namely, we compare the logistics sector to manufacturing firms, business service firms and transport operators. First, we look at the mean distances of these firms in relation to the transportation networks. Logistics firms are on average located closer to each of the transportation infrastructure analyzed. Logistics firms locate closer to highways, airports and seaports than firms in other sectors. Looking at the percentage of firms that locates in a distance of 1, 5, and 10 kilometres from a highway, we can also see that logistics firms are strongly attracted to the highway network. More than $95 \%$ of our logistics firms are located within $10 \mathrm{~km}$ of a highway and nearly half of our logistics firms are within 1 kilometre of a highway. Other sectors are also attracted to the highway network, but this attraction is particularly strong for logistics firms.

The logistics sector is also a typical urbanized sector. Looking at the mean population density of the municipality where the firm is located, one can observe that logistics firms are on average in municipalities with higher population density; even more than business service firms. About $89 \%$ of logistics firms are located in urban areas and only $11 \%$ in rural areas. The logistics sector is considerably more urbanized than the manufacturing sector or the transportation sector in general.

Nevertheless, as shown in Figure 3 (in Appendix), this pattern has changed considerably over the last decades. Figure 3 plots the share of rural, suburban and CBD logistics firms according to their year of establishments. Logistics firms that had been established before 1982 showed a much stronger tendency to locate in CBD municipalities. 80\% of them located in CBD municipalities, about $17 \%$ in suburban areas, and only $3 \%$ in rural areas. Over time, the percentage of CBD location has been falling to about 50\%, while the percentage of logistics firms that located in suburban and rural municipalities has been increasing to 30 and $14.5 \%$ respectively. We also observe that since the 1980's, the average distance of new logistics establishments to the CBD of their closest urban area more than doubled with an increase from 4.8 kilometres to 10.4 kilometres. This shows that new logistics firms have located increasingly in suburban and extra-urban locations.

Even though the percentage of logistics firms locating in extra-urban locations is still relatively low, it is interesting to ask which type of logistics firms has located in rural areas and which type of rural municipalities has been able to attract logistics firms. Comparing the mean age of logistics firms in rural versus urban areas we observe that the mean age is considerably lower with 8.5 years compared to 12 years for urban logistics firms. This difference is much more pronounced than in other sectors. For example, in manufacturing, the difference is only 0.7 years, in the business service sector and in the transportation sector; in general the difference is about 1 year. We also observe that it is mainly logistics firms in warehousing and storage, related to land transportation, cargo handling and other transportation support activities that have located in rural areas. In contrast, logistics firms related to air and water transportation show a lower probability to locate in rural areas. Table 3 compares the characteristics of rural municipalities that have not received any new logistics firm in the period 2002-2007 to those rural municipalities that have received new logistics firms. First, we start with our accessibility variables. Rural municipalities that have received logistics firms have higher market potential and are significantly closer to highways, airports and seaports. They are also considerably larger in terms of population and manufacturing employment and have a much higher population density. In this sense, they are the least "rural" ones. They are 
furthermore closer to urban areas than rural municipalities that have not received any new logistics firms. However, they are at further distance from the two big metropolitan areas Madrid and Barcelona. This could indicate a certain shadow effect of these metropolitan areas.

\subsection{Modelling the location determinants of logistics firms}

Next, we investigate the location determinants of new logistics firms with a focus on accessibility and access to transportation infrastructure and urban structure. Here we analyze the location behaviour of new logistics firms that have been created between 2002-2007 (both years inclusive). Firm location is not a random process, but the result of profit maximizing location decisions, where the location decision is based on the future profits that a firm expects to earn in that location.

This profit-maximizing framework leads to McFadden's (1974) random profit maximization-based conditional logit model. However, the implementation of the conditional logit model faces several problems in cases like ours where we have a very large set of spatial alternatives. Alternatively, one can adopt a count data modelling approach. In this case, the dependent variable is the count of new logistics firms that have been established in a municipality. Count data can be approximated by a Poisson distribution. More specifically, under certain condition a Poisson model will yield identical results as the conditional logit model (Guimarães et al., 2003; Schmidheiny and Brülhart, 2011).

We follow the count data approach and our estimating equation can be expressed as follows:

$$
n_{i 2002-2007}=f\left(x_{j 2001}\right)+\varepsilon_{j}
$$

where nj2002-2007 is the count of new logistics firms located in municipality $\mathrm{j}$ in our study period. $x \mathrm{j} 2001$ is a vector of municipality characteristics referring to the year before

the start of our analysis. ${ }^{\varepsilon_{j}}$ is a random error term. The independent variables include in xj2001 are municipality characteristics that can be expected to affect the profits of logistics firms. Our focus lies on the role of our accessibility variables describe before. Furthermore, we include a number of variables to characterize the urban structure of municipalities. In addition, we include a set of control variables that can be classified in two groups: socio-economic controls and physical geography controls. Socio-economic controls reflect business conditions in the municipality and include base year municipality population and manufacturing employment together with the percentage of occupied population to indicate the size of the local market. We also account for education by including the percentage of graduates in the base year as a proxy of the qualification of the workforce and we include previous population growth. As for physical geography controls, we include in our analysis the municipality latitude and longitude, land area and altitude and the distance from the each municipality to the nearest coast.

One of the key characteristics of our data is that it is strongly over dispersed as already indicated in Table 1. Table 3 shows that the distribution of new logistics firms created in the period 2002-2007 is even more spatially concentrated in a relatively small number of locations. Indeed, the mean number of new logistics firms per municipality in our study 
period is 0.3 , while the standard deviation is 3.9. Only 697 municipalities have received a new logistics firm over the period analyzed. Moreover, 30 municipalities concentrate about $95 \%$ of all new logistics firm locations. Only two municipalities - Madrid and Barcelona - show over 100 newly created logistics firms over this period. Together they account for about $43 \%$ of new logistics firms created in the 2002-2007 period.

In the Poisson model the mean and the variance are constrained to be equal. In our data, this assumption is however violated due to over-dispersion. The negative binomial model relaxes this restriction. In order to further test if the number of zeroes is in excess of what would be expected from a negative binomial model, we also run a zero-inflated negative binomial model and test whether it better predicts our dependent variable than a standard negative binomial model. The zero outcome of logistics location can arise from two underlying responses. Some municipalities may never attract a logistics firm and the outcome will always be zero. One could think about remote rural areas or mountainous municipalities, which would not even be considered by logistics firms in their location choice process. If the municipality has, however, some attraction potential, we could still observe a zero outcome in the period considered, but the municipality could have attracted logistics firms in different periods. A zero-inflated model allows distinguishing between these two processes. First, a logit model is generated for the "certain" zero cases, predicting whether a municipality would be in this group. Here we include as additional inflation variable the stock of logistics firms in 2001. Then, a negative binomial model is generated predicting the counts of new logistics firms for those municipalities that are not "certain" zeros. To test for the choice between the negative binomial and the zeroinflated negative binomial we use Vuong's (1989) likelihood ratio test for non-nested models. 4

\subsection{Estimation results}

Table 4 shows our estimation results. We first present in column 1 the results from the estimation of the Poisson (POIS) model. However, we cannot maintain the null hypothesis of equi-dispersion and therefore proceed with the estimation of the negative binomial (NBREG) model (column 2). Columns 3 to 7 show the results from the zeroinflated negative binomial model (ZINB). The Vuong test compares the zero-inflated negative binomial model to a standard negative binomial model. Since the $\mathrm{z}$-value is significant in all our specifications, the Vuong test shows that the zero-inflated negative binomial provides a better fit than the standard negative binomial. We therefore base our discussion of how accessibility and urban structure affect logistics firm location on the results of the different specification of the ZINB model.

In column 3 we only include our accessibility variables. Province fixed effects are included as control. Market potential shows the expected positive effect and the distances to the nearest highway, airport and seaport are all statistically significant and negative indicating that logistics firms prefer locating close to transportation infrastructure.

In column 4 we add variables characterizing the urban structure. Specifically we include a dummy for CBD municipalities (excluding Madrid and Barcelona) and two dummies for municipalities that are within a distance of $20 \mathrm{~km}$ from Madrid and Barcelona, respectively. These dummies are highly significant and positive. Despite a certain

\footnotetext{
${ }^{4}$ We have also tried to estimate hurdle models, however, we were unable to achieve convergence in these models.
} 
tendency of logistics firms to locate increasingly also in rural areas, urban areas are still the main attractions for logistics firms. Conditional on the urban characteristics of the location, access to transportation infrastructure remains statistically significant. However, market potential is no longer significant once the urban structure is controlled for. This might be due to certain correlation between market potential and urbanity. In column 5 we experiment with a slightly different characterization of urban structure. We include three separate dummies for CBD municipalities: one for Madrid, one for Barcelona and one for the remaining CBD municipalities and we add dummies for suburban areas. In the case of Madrid and Barcelona we add dummies for municipalities that fall into a distance of 20 kilometres. In the case of the remaining urban areas - which are all considerably smaller - we allow for a influence area of 10 kilometres. These results confirm the strong attraction of logistics firm to the Madrid and Barcelona area. The dummy variable for other CBD municipalities remains significant but their surrounding areas have not shown a higher probability of attracting logistics firms than rural areas, which are the comparison group. Results regarding our accessibility variables remain virtually unchanged. In column 6 we add our geographic controls to the estimation. Results remain very similar. Only the market potential variable gains now again significance. However, once we also add socio-economic controls in column 7 this significance of the market potential variable is again lost. All other results are robust to the inclusion of geographic and socio-economic controls. The ambiguous findings regarding market potential are most likely because market potential is highest in the large urban and metropolitan areas, which is captured in part by our urban structure dummies, and market potential is correlated with our socio-economic controls. Nevertheless, including our detailed geographic and socio-economic controls reduces potential endogeneity problems. For example, transportation infrastructure is likely to be placed in areas of high economic activity which is controlled for by our socio-economic base year controls. High economic activity in an area in turn will also be an attraction factor for logistics firms.

Our results indicate a clear role of transportation infrastructure as determinant of logistics firm location. Since logistics is about managing the supply chains from raw materials to the final product and service delivery, and this is expected to happen at ever-faster speed, the logistics sector is reliant on good access to fast and efficient transportation infrastructure. 


\section{Working papers SIET 2016 - ISSN 1973-3208}

Table 4: Logistics firm location: Poisson, negative binomial and zero inflated negative binomial estimation

\begin{tabular}{|c|c|c|c|c|c|c|c|}
\hline & POIS & NBREG & ZINB & ZINB & ZINB & ZINB & ZINB \\
\hline & (1) & (2) & (3) & (4) & (5) & (6) & (7) \\
\hline \multicolumn{8}{|l|}{ Accessibility: } \\
\hline $\log$ (market potential) & $\begin{array}{l}0.169 \\
(0.529)\end{array}$ & $\begin{array}{l}1.108^{* *} \\
(0.454)\end{array}$ & $\begin{array}{l}0.351 * * \\
(0.177)\end{array}$ & $\begin{array}{l}-0.200 \\
(0.180)\end{array}$ & $\begin{array}{l}0.149 \\
(0.180)\end{array}$ & $\begin{array}{l}0.444^{* *} \\
(0.222)\end{array}$ & $\begin{array}{l}-0.210 \\
(0.222)\end{array}$ \\
\hline log (highway distance) & $\begin{array}{l}-0.390^{* * *} \\
(0.055)\end{array}$ & $\begin{array}{l}-0.630^{* * *} \\
(0.075)\end{array}$ & $\begin{array}{l}-0.337 * * * \\
(0.050)\end{array}$ & $\begin{array}{l}-0.158^{* * *} \\
(0.039)\end{array}$ & $\begin{array}{l}-0.118^{* * *} \\
(0.036)\end{array}$ & $\begin{array}{l}-0.125^{* * *} \\
(0.035)\end{array}$ & $\begin{array}{c}-0.067 * * \\
(0.031)\end{array}$ \\
\hline $\log$ (airport distance) & $\begin{array}{l}-0.391 * * * \\
(0.108)\end{array}$ & $\begin{array}{l}-0.383^{* * *} \\
(0.120)\end{array}$ & $\begin{array}{l}-0.250^{* * *} \\
(0.061)\end{array}$ & $\begin{array}{l}-0.155^{* * *} \\
(0.051)\end{array}$ & $\begin{array}{l}-0.137^{* * *} \\
(0.045)\end{array}$ & $\begin{array}{l}-0.147^{* * *} \\
(0.044)\end{array}$ & $\begin{array}{l}-0.096^{* * *} \\
(0.035)\end{array}$ \\
\hline $\log$ (seaport distance) & $\begin{array}{l}-0.429 * * * \\
(0.104)\end{array}$ & $\begin{array}{l}-0.549 * * * \\
(0.093)\end{array}$ & $\begin{array}{l}-0.097 * * * \\
(0.034)\end{array}$ & $\begin{array}{l}-0.160^{* * *} \\
(0.041)\end{array}$ & $\begin{array}{l}-0.148^{* * *} \\
(0.037)\end{array}$ & $\begin{array}{l}-0.147^{* * *} \\
(0.049)\end{array}$ & $\begin{array}{l}-0.074 * * \\
(0.037)\end{array}$ \\
\hline \multicolumn{8}{|l|}{ Urban structure: } \\
\hline CBD dummy (without & & & & $2.049 * * *$ & $2.023^{* * *}$ & $1.663^{* * *}$ & $0.238^{*}$ \\
\hline Madrid and Barcelona) & & & & $(0.121)$ & $(0.116)$ & $(0.115)$ & $(0.134)$ \\
\hline $\begin{array}{l}\text { Within } 20 \mathrm{~km} \text { of Madrid (incl. } \\
\text { Madrid) }\end{array}$ & & & & $\begin{array}{l}3.246 * * * \\
(0.258)\end{array}$ & & & \\
\hline $\begin{array}{l}\text { Within } 20 \mathrm{~km} \text { of Barcelona } \\
\text { (incl. Madrid }\end{array}$ & & & & $\begin{array}{l}2.004^{* * *} \\
(0.241)\end{array}$ & & & \\
\hline CBD dummy Madrid & & & & & $\begin{array}{l}5.744 * * * \\
(0.841)\end{array}$ & $\begin{array}{l}4.838 * * * \\
(0.776)\end{array}$ & $\begin{array}{l}1.601^{* * *} \\
(0.578)\end{array}$ \\
\hline CBD dummy Barcelona & & & & & $\begin{array}{l}4.490 * * * \\
(0.848)\end{array}$ & $\begin{array}{l}3.658^{* * *} \\
(0.779)\end{array}$ & $\begin{array}{l}1.403^{* *} \\
(0.564)\end{array}$ \\
\hline Around $20 \mathrm{~km}$ of Madrid & & & & & $\begin{array}{l}1.645^{* * *} \\
(0.274)\end{array}$ & $\begin{array}{l}1.612^{* * *} \\
(0.293)\end{array}$ & $\begin{array}{l}0.432 * \\
(0.262)\end{array}$ \\
\hline Around $20 \mathrm{~km}$ of Barcelona & & & & & $\begin{array}{l}1.092^{* * *} \\
(0.241)\end{array}$ & $\begin{array}{l}1.057 * * * \\
(0.234)\end{array}$ & $\begin{array}{l}0.388^{* *} \\
(0.201)\end{array}$ \\
\hline Around $10 \mathrm{~km}$ of other CBD's & & & & & $\begin{array}{l}-0.088 \\
(0.107)\end{array}$ & $\begin{array}{l}0.131 \\
(0.108)\end{array}$ & $\begin{array}{c}-0.150 \\
(0.097)\end{array}$ \\
\hline \multicolumn{8}{|l|}{ Additional inflation variable } \\
\hline Stock of logistics firms 2001 & & & $\begin{array}{l}-2.354^{* * *} \\
(0.292)\end{array}$ & $\begin{array}{l}-2.390 * * * \\
(0.336)\end{array}$ & $\begin{array}{l}-2.209 * * * \\
(0.289)\end{array}$ & $\begin{array}{l}-1.750^{* * *} \\
(0.237)\end{array}$ & $\begin{array}{l}-0.907 * * * \\
(0.237)\end{array}$ \\
\hline Province fixed effects & $\mathrm{Y}$ & $\mathrm{Y}$ & $\mathrm{Y}$ & $\mathrm{Y}$ & $\mathrm{Y}$ & $\mathrm{Y}$ & Y \\
\hline Geographic controls & $\mathrm{N}$ & $\mathrm{N}$ & $\mathrm{N}$ & $\mathrm{N}$ & $\mathrm{N}$ & Y & Y \\
\hline Socio-economic controls & $\mathrm{N}$ & $\mathrm{N}$ & $\mathrm{N}$ & $\mathrm{N}$ & $\mathrm{N}$ & $\mathrm{N}$ & $\mathrm{Y}$ \\
\hline Observations & 7936 & 7936 & 7936 & 7936 & 7936 & 7939 & 7639 \\
\hline Pseudo R-squared & 0.387 & & & & & & \\
\hline Log likelihood & -5871.7 & -2959.9 & 2693.9 & 2438.9 & 2395.3 & 2303.9 & 2065.8 \\
\hline Vuong Test- ZINB v NegBin & & & $12.8^{* * *}$ & $12.2^{* * *}$ & $11.9^{* * *}$ & $10.1 * * *$ & $6.7^{* * *}$ \\
\hline
\end{tabular}

Note: (1) Robust standard errors reported in parenthesis. Significant coefficients are indicated by $* * *, * *, *$, for significance at the 1\%,5\% and 10\% level, respectively. (2) Geographic controls include: Latitude, Longitude, Distance to the coast, Land area, Altitude. (3) Socio-economic controls include: $\log$ of 2001 municipality population, $\log$ of 1991-2001 population growth, $\log$ of 2001 manufacturing employment, percentage of graduates in 2001, percentage of occupied population in 2001. 


\section{Conclusion}

The literature on firm location has mainly concerned the manufacturing industry, and recently the service sector, while little evidence has yet been provided on the logistics sector. The few studies on the topic refer mainly to logistics sprawl of warehousing activities at the regional/metropolitan level and to the location determinants of transport and logistics FDIs in China and Italy.

However, in the globalized world, where the demand for "logistics floor space" is expected to grow substantially, understanding the location decisions of logistics firms is important for society. Besides, it cannot be denied the positive contribution of logistics to global economic growth as well as of ICT and logistics to the global production efficiency.

Within this context, the present paper contributes to the literature empirically by investigating the geography of logistics firms and the role played by accessibility using geo-referenced firm level data along with detailed information on transport infrastructure for the whole of Spain. To reach this goal, a spatial analysis together with a count data modelling approach has been adopted. The spatial analysis refereed to the year 2007 and confirmed a strong concentration of logistics firms in the main urban areas - with Madrid and Barcelona hosting one third of the establishments -, in major cities and along major transportation corridors, with a preference for the highway network. Besides, if compared to the manufacturing, business and transport sectors, logistics firms are more urbanized. However, this trend started decreasing since the 1980s in favour of suburban and extraurban locations. Specifically, rural areas with good accessibility, higher market potential, and higher proximity to urban areas began to attract warehousing, storage, cargo handling operations, and other transport support activities.

The results of the spatial analysis are corroborated by the count data modelling approach focusing on the new logistics firms that have been created in the period 2002-2007. Access to transportation infrastructure and proximity to urban areas (especially Madrid and Barcelona) are important location determinants for logistics firms, thus confirming the attitude of this sector, which is market oriented, to be located in or close to urban areas. Our results confirm that transportation accessibility is crucial for the emergence of logistics clusters.

Nevertheless, as suggested by the literature, logistics sprawl is occurring too: these firms are increasingly privileging suburban locations and, to some extent, rural locations with good accessibility to the detriment of central cities, likely due to their lower factor prices and land availability. These results are meaningful for policymakers: the location of logistics activities raises land consumption, contributes to urban sprawl, and is a generator of negative external costs for the community. Besides, it shapes the demand for freight transport and deeply influences the feasibility of a shift of freight transport towards more sustainable modes of transport (European Commission, 2011).

Further research might investigate whether government policies might have played a role in accommodating new logistics firms in Spain, and how and to what extent tailored planning policies might reduce land consumption sprawl as well as the collective costs. Besides, an analysis of the new established firms in other sectors (i.e. manufacturing, retail, business) in the period of analysis (2002-2007) might help improving further our 
understanding of whether and how the logistics' location behaviour differs from the other sectors' location behaviour. Investigating the relationship between location dynamics and logistics firms' heterogeneity (domestic vs. foreign owned firms) might also provide useful information to government policy makers in predicting future location patterns. In the case of FDIs, for instance, appropriate public policies might be designed to influence their future location decisions.

A final note of caution must be added. We cannot be completely sure that the relationships that we have observed in our analysis between logistics firm location and our accessibility measures are causal. More research still needs to be done in this field to address remaining concerns regarding the endogeneity in infrastructure placement and thus the potential for reverse causality between accessibility and logistics location.

\section{References}

Allen, J., and Browne, M. (2010) Considering the relationship between freight transport and urban form. Green Logistics Report: http://www.greenlogistics.org/themesandoutputs/wm9/downloads/Freight\%20transpor t\%20and\%20urban\%20form\%20Final\%20September\%202010.pdf.

Arndt, S.W., and Kierzhowsky, H. (2001) Fragmentation. New Production Patterns in the World Economy. Oxford: Oxford University Press.

Arnold, J., Arvis, J. F., and Mustra, M.A. (2010) Trade and Transport Facilitation Assessment: A Practical Toolkit to Improve the Trade Logistics and Competitiveness of Countries, Herndon, VA, USA: World Bank Publications.

Arvis, J. F. Mustra M.A., Panzer J., Ojala L., Naula T. (2007) Connecting to compete: trade logistics in the global economy, Washington: The World Bank. International Trade Department, Washington DC.

Bonacich, E. and Wilson, J.B. (2008) Getting the Goods: Ports, Labor, and the Logistics Revolution, Ithaca, NY, USA: Cornell University Press. p 241.

Boscacci F., Maggi E., Mariotti I. (2009) Le determinanti localizzative delle imprese logistiche a capitale estero presenti in Italia. In Marletto G., Musso E. (a cura di), Trasporti, ambiente e Territorio. La ricerca di un nuovo equilibrio, Franco Angeli, Milano, pp. 267-275.

Bowen J.T. (2008) Moving places: the geography of warehousing in the US, Journal of Transport Geography 16: 379-387.

Brouwer A., Holl A., Mariotti I. (2013) What drives logistics employment growth? An empirical investigation in the EU. In Bergantino A.S., Carlucci F., Cirà A., Marcucci E., Musso E. (a cura di), I sistemi di trasporto nell'area del Mediterraneo: infrastrutture e competitività, Franco Angeli, Milan, pp. 138-148.

Casson M. (1994) Why are firms hierarchical?, Journal of the Economics of Business, 1, 1: 47-76.

Coto-Millàn P., Fernandez X.L., Pesquera M.A., Agueros M. (2015) Impact of logistics on technical efficiency of world production (2007-2012), Netw Spat Econ , DOI 10.1007/s11067-015-9306-6, pp.1.15 
Dablanc, L. S. Ogilvie, A. Goodchild (2014) Logistics Sprawl: Differential Warehousing Development Patterns in Los Angeles and Seattle, Transportation Research Board, 2410: 105-112.

Dablanc L., Ross C. (2012) Atlanta: A Mega Logistics Center in the Piedmont Atlantic Megaregion (PAM). Journal of Transport Geography, 24, pp.432-442.

Daniels, P.W. (1985). Service Industries: A Geographical Appraisal. Methuen \& Co, New York.

European Commission (2011) Roadmap to a single European transport area - Towards a competitive and resource efficient transport system. White Paper, including the Impact Assessment, Brussells.

Ferrari C., Parola F., Tei A. (2011) Northern Africa and International Trade Networks: Port Investments and Market Opportunities. In: T. NOTTEBOOM. Current Issues in Shipping, Ports and Logistics. University Press Antwerp, ANTWERP: pp. 203-220.

Glaeser, E.L. and Kohlhase, J.E. (2004) Cities, regions and the decline of transport costs. Papers in Regional Science 83: 197-228.

Groot H.L.F. (2001) Macroeconomic consequences of outsourcing: an analysis of growth, welfare and product variety, De Economist, 149 (1): 53-79.

Guimarães, P., Figueiredo, O., Woodward, D.P. (2003) A Tractable Approach to the Firm Location Decision Problem, Review of Economics and Statistics 85 (1): 201-204.

Harris, C.D. (1954) The market as a factor in the localization of industry in the United States, Annals of the Association of American Geographers 44(4), 315-348.

Head K., Mayer T. (2004) Market Potential and the Location of Japanese Investment in the European Union, The Review of Economics and Statistics, MIT Press, vol. 86(4): 959-972.

Head K. and Ries J. (1996) Inter-city competition for foreign investment: static and dynamic effects of China's incentive areas, Journal of Urban Economics 40: 38-60.

Helg, R. and Tajoli, L. (2005) Patterns of international fragmentation of production and the relative demand for labor, North American Journal of Economics and Finance 16: 233-254.

Hesse M. (2004) Land for logistics: locational dynamics, real estate markets and political regulation of regional distribution complexes, Tijdschrift voor Economische en Sociale Geographie 95(2): 162-173.

Hesse M., Rodrigue J.P. (2004) The transport geography of logistics and freight distribution, Journal of Transport Geography 12: 171-184.

Hofstede G. (1980), Culture's Consequences: International Differences in Work-Related Values, Beverly Hills CA: Sage Publications.

Holl, A. (2004) Manufacturing location and impacts of road transport infrastructure: Empirical evidence from Spain, Regional Science and Urban Economics 34 (3): 341363.

Holl, A. (2016) Highways and productivity in manufacturing firms, Journal of Urban Economics 93: 131-151.

Hong J. (2007) Transport and location of foreign logistics firms: the Chinese experience, Transportation Research Part A, 41: 597-609.

Hong J. (2010), Firm-specific effects on location decisions of foreign direct investments in China's logistics industry, Regional Studies, 41.5: 673-683.

Hong J.J. \& Chin A. (2007) Modeling the location choices of foreign investments in Chinese logistics industry, China Economic Review, 18: 425-437. 
Hummels D., (1999) Have International Transportation Costs Declined? Department of Economics Working Paper, Purdue University, (USA).

Lai, Kee-hung and Cheng, T.C.E. (2009) 'Just-in-Time Logistics', Abingdon, Oxon, GBR: Ashgate Publishing Group.

Levinson M. (2006) The Box: How the Shipping Container Made the World Smaller and the World Economy Bigger. Princeton University Press.

Jing, N., Cai, W. (2010) Analysis on the spatial distribution of logistics industry in the

Maggi E. and Mariotti I. (2012) Globalisation and the rise of logistics FDI: the case of Italy, in DeSare T., Caprioglio D., eds., Foreign Investment: Types, Methods and Impacts, Nova Science Publishers, pp.29-60.

Mariotti S. and Piscitello L. (1995) Information Costs and Location of FDIs within the Host Country: empirical evidence from Italy, Journal of International Business Studies, fourth quarter, 815-841.

Mariotti I. (2015) Transport and logistics in a globalizing world. A focus on Italy, Springer, Heidelberg-New York.

Mariotti I., Maltese I., Boscacci F. (2012) Location choice of inward logistics FDI in Italy, in Campagna M., De Montis A., Isola F., Lai S., Pira C., Zoppi C. (eds.) (2012), Planning Support Tools: Policy Analysis, Implementation and Evaluation, FrancoAngeli, Milano, pp. 1695-1708.

Markusen, J.R., Rutherford, T., and Tarr, D.G. (2005) Trade and Direct Investment in Producer Services and the Domestic Market for Expertise. Canadian Journal of Economics, 38(3):758-777.

McCann P. (2008), Globalisation and economic geography: the world is curved, not flat, Cambridge Journal of Regions, Economy and society, 1: 351-370.

McFadden, D. (1974) Conditional logit analysis of qualitative choice behaviour. In: Zarembka, P. (Ed.), Frontiers in econometrics. Academic Press, New York.

McKinnon, A. (1988) Physical Distribution. In: Marshall, J.N. (Ed.), Services and Uneven Development. Oxford University Press, Oxford, pp. 133-159.

McKinnon A. (2009) Logistics and land: the changing land use requirements of logistical activity. Paper presented at the 14th Annual Logistics Research Network Conference, 9th-11th September, Cardiff, UK.

Mori T., Nishikimi K. (2002) Economies of transport density and industrial agglomeration, Regional Science and Urban Economics 32: 167-200.

Notteboom, T. (2007) Strategic challenges to container ports in a changing market environment. Devolution, Port Governance and Port Performance Research in Transportation Economics 17: 29-52.

Notteboom T., Rodrigue J.P. (2009) The Geography of Containerization: Half a Century of Revolution, Adaptation and Diffusion, Geojournal, vol. 74 (1): 1-5.

O'Connor K. (2010), Global city regions and the location of logistics activity, Journal of Transport Geography, 18 (3): 354-362.

Oum T.H. and Park J.H. (2004) Multinational firms' location preference for regional distribution centers: focus on the North-east Asian region, Transportation Research Part E, 40: 101-121.

Radner R.( 1992) Hierarchy: The economics of managing, Journal of Economic Literature, 30 (3): 1382-1415.

Reggiani A. (1998) Accessibility, trade and location behaviour: an introduction. In Reggiani A. (ed) Accessibility, trade and location behaviour. Ashagate, Aldershot, pp $1-16$ 
Rietveld,P. and F. Bruinsma (1998) Is transport infrastructure effective?: transport infrastructure and accessibility: impacts on the space economy. Advances in Spatial Science, Springer, Berlin.

Ruiz, F. (2010) Âreas Urbanas de España. Proyecto AUDES. Universidad de Castilla-La Mancha. http://alarcos.esi.uclm.es/per/fruiz/audes/.

Schmidheiny, K. and Brulhart, M. (2011) On the equivalence of location choice models: Conditional logit, nested logit and Poisson, Journal of Urban Economics 69(2): 214222.

Sivitadinou, R. (1996) Warehouse and distribution facilities and community attributes: an empirical study. Environment and Planning A, 28: 1261-1278.

Vahrenkamp R. (2010). Driving globalization: the rise of logistics in Europe 1950-2000. European Transport, n.45: 1-14.

Van Den Heuvel F.P., De Langen P.W., Van Donselaar K.H., Fransoo J.C. (2013) Spatial concentration and location dynamics in logistics: the case of a Dutch province, Journal of Transportation Geography 28: 39-48.

Van Veen-Groot D.B. and Nijkamp P. (1999) Globalisation, transport and the environment: new perspectives for ecological economics. Ecological Economics 31: 331-346.

Verhetsel, A., R. Kessels, P. Goos, T. Zijlstra, N. Blomme, J. Cant (2015) Location of logistics companies: a stated preference study to disentangle the impact of accessibility, Journal of Transport Geography 42: 110-121.

Vuong, Q. H. (1989) Likelihood ratio tests for model selection and non-nested hypotheses, Econometrica 57: 307-333.

Wood, D. F., Barone, A., and Murphy, P. (2002) 'International Logistics', Saranac Lake, NY, USA: AMACOM Books. p 412.

Xiushan J, Lei Z, Chenfeng X, Ruijun W (2015) Transportation and regional economic development: analysis of spatial spillovers in China provincial regions. Netw Spat Econ. Doi: 10.1007/s11067-015-9298-2

\section{Acknowledgements}

This research has benefitted from financial support from the Fundación BBVA (I Convocatoria de Ayudas Fundación BBVA a Investigadores, Innovadores y Creadores Culturales). An earlier version of this study was presented at the ERSA 2015 congress in Lisbon, at the URSI seminar at the University of Groningen in 2015, and at the SIET 2016 conference in Genoa. We thank these audiences. 
Working papers SIET 2016 - ISSN 1973-3208

Appendix 1:

Definitions and sources of municipality control variables

\begin{tabular}{|c|c|c|}
\hline & Definition & Sources \\
\hline Population 2001 & Log (population 2001) & INE (www.ine.es) \\
\hline $\begin{array}{l}\text { Population growth } 1991 \text { - } \\
2001\end{array}$ & $\begin{array}{l}\log (\text { population 2001)- } \\
\log (\text { population 1991) }\end{array}$ & INE (www.ine.es) \\
\hline $\begin{array}{l}\text { Manufacturing } 2001 \\
\text { \% graduate } 2001\end{array}$ & $\begin{array}{l}\log \text { (employed in manufacturing in } \\
2001) \\
\text { Residents with a hioher education }\end{array}$ & \\
\hline \% employed 2001 & $\begin{array}{l}\text { degree in 2001/ Resident population } \\
\text { in 2001] x } 100 \\
\text { [Residents which were employed in } \\
\text { 1991/ Resident population in 1991] } \\
\text { x } 100\end{array}$ & $\begin{array}{l}\text { Census data } 2001 . \\
\text { INE (www.ine.es) }\end{array}$ \\
\hline Latitude & --- & $\begin{array}{c}\text { National Geographic } \\
\text { Institute }\end{array}$ \\
\hline Longitude & --- & $\begin{array}{l}\text { National Geographic } \\
\text { Institute }\end{array}$ \\
\hline Altitude & --- & $\begin{array}{l}\text { National Geographic } \\
\text { Institute }\end{array}$ \\
\hline Distance to the coast & $\begin{array}{l}\text { Geodesic distance to nearest coast } \\
\text { line }\end{array}$ & $\begin{array}{l}\text { GIS own calculation based } \\
\text { on National Geographic } \\
\text { Institute data }\end{array}$ \\
\hline Land area & in square kilometers & INE (www.ine.es) \\
\hline$C B D$ dummy & $\begin{array}{l}\text { Dummy variable taking } 1 \text { if } \\
\text { municipality is the central city of an } \\
\text { AUDES urban area }\end{array}$ & $\begin{array}{c}\text { Proyecto AUDES: } \\
\text { http://alarcos.esi.uclm.es/pe } \\
\text { r/fruiz/audes/ }\end{array}$ \\
\hline
\end{tabular}


Figure 1. Location of logistics firms in mainland Spain in 2007

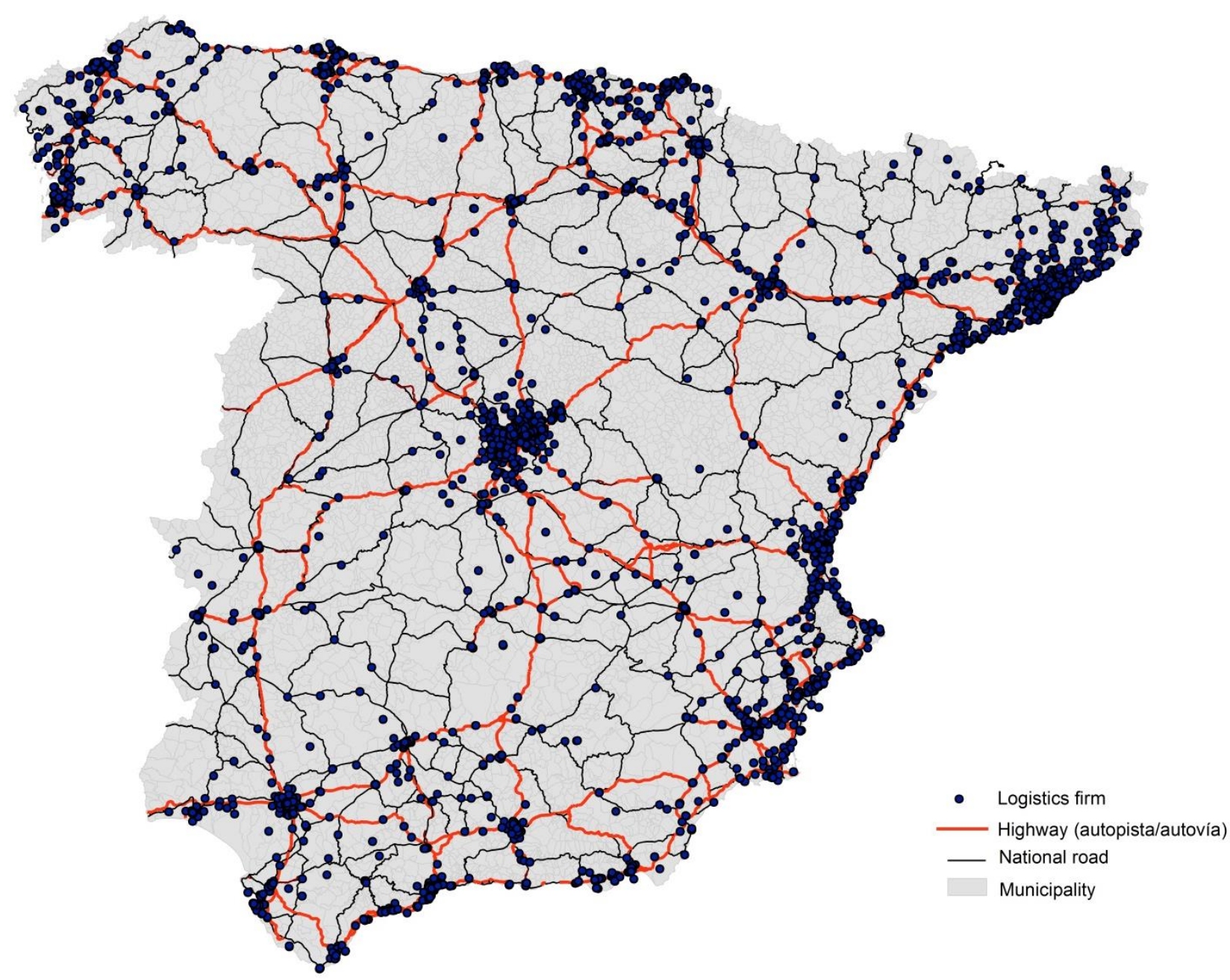


Figure 2. Location of logistics firms in Madrid and Barcelona in 2007

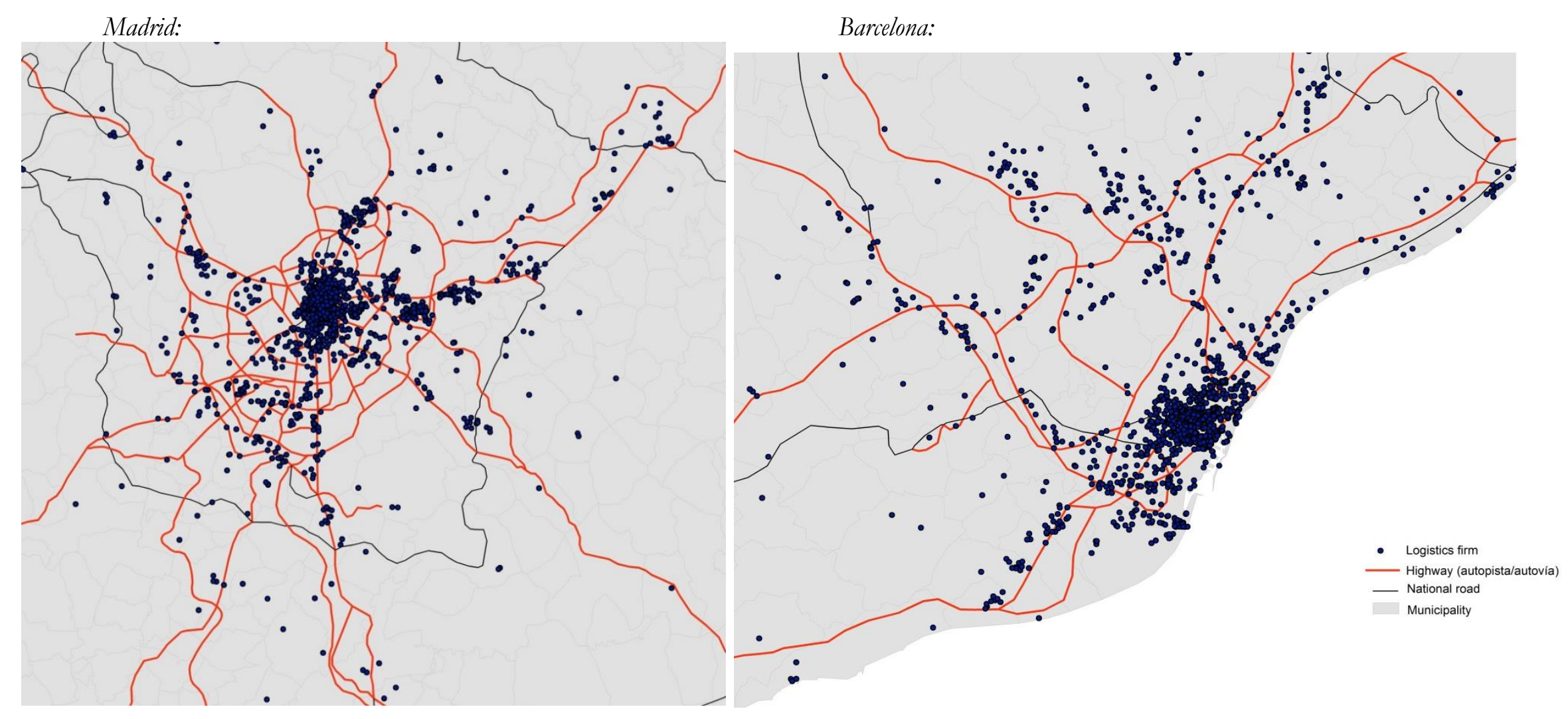

